\title{
Pengembangan Bahan Ajar Aljabar Linier Berbasis Nilai-nilai Keislaman dengan Pendekatan Saintifik
}

\author{
Dona Dinda Pratiwi \\ Universitas Islam Negeri Raden Intan Lampung. Jalan Endro Suratmin, Sukarame, \\ Bandar Lampung 35133, Indonesia. \\ *Corresponding Author. E-mail: donadinda@radenintan.ac.id
}

\begin{abstract}
Abstrak
Tujuan penelitian ini adalah menghasilkan bahan ajar aljabar linier berbasis nilai-nilai keislaman dengan pendekatan saintifik pada materi matriks dan sistem persamaan linier yang layak dan sesuai kebutuhan mahasiswa. Metode penelitian ini adalah Research and Development $(R \& D)$ dengan model yang digunakan yaitu model $A D D I E$ yang terdiri dari lima tahap yaitu Analysis, Design, Development, Implementation, Evaluation. Validasi dilakukan oleh ahli materi, ahli media dan ahli ahli agama serta respon dari mahasiswa. Instrumen yang digunakan yaitu berupa lembar angket validasi dan lembar respon mahasiswa. Berdasarkan penelitian diperoleh hasil validasi ahli materi dengan presentase $84 \%$ dengan kategori "Sangat Layak", hasil validasi ahli media dengan presentase $76 \%$ dengan kategori "Layak", hasil validasi ahli agama dengan presentase $76 \%$ dengan kategori "Layak" dan setelah dikembangkan, bahan ajar diimplementasikan atau diujicobakan untuk mengetahui respon mahasiswa dengan presentasi 88\% kategori "Sangat Baik". Berdasarkan penelitian pengembangan ini kelebihan bahan ajar tersebut yaitu materi bahan ajar berkaitan dengan nilai-nilai keislaman dan pendekatan saintifik.
\end{abstract}

Kata kunci: Bahan Ajar, Nilai-nilai Keislaman, Pendekatan Saintifik.

\section{Abstract}

The purpose of this study is to produce linear algebra teaching materials based on Islamic values with a scientific approach to matrix material and a system of linear equations that are appropriate and appropriate to the needs of students. This research method is Research and Development $(R \& D)$ with the model used, namely the ADDIE model which consists of five stages, namely Analysis, Design, Development, Implementation, Evaluation. Validation was carried out by material experts, media experts and experts in religious studies and responses from students. The instruments used were in the form of validation questionnaires and student response sheets. Based on the research, the results of material expert validation with a percentage of $84 \%$ with the category "Very Worthy", the results of media expert validation with a percentage of $76 \%$ with the category "Eligible", the results of the validation of religious experts with a percentage of $76 \%$ with the category "Eligible" and after development, material Teachers are implemented or tested to find out student responses with 88\% presentation in the "Very Good" category. Based on this research development the advantages of the teaching materials are teaching material related to Islamic values and scientific approaches.

Keywords: Teaching Materials, Islamic Values, Scientific Approach.

\section{PENDAHULUAN}

Bahan ajar merupakan bagian yang penting dalam pembelajaran karena dapat digunakan sebagai sumber belajar baik bagi dosen maupun mahasiswa. Mulyasa dalam (Mardiana, 2018) mengemukakan bahwa bahan ajar merupakan salah satu bagian dari sumber belajar yang dapat diartikan sesuatu yang mengandung pesan pembelajaran, baik yang bersifat khusus maupun yang bersifat umum yang dapat dimanfaatkan untuk kepentingan pembelajaran. Sedangkan menurut Widodo dan Jasmadi dalam (Kusumam, Mukhidin, \& Hasan, 
2016) menyatakan bahwa bahan ajar adalah seperangkat sarana atau alat pembelajaran yang berisikan materi pembelajaran, metode, dalam rangka mencapai tujuan yang diharapkan. Pemilihan dan penggunaan sumber belajar yang tepat dalam suatu aktivitas dan proses pembelajaran berperan penting dalam mengarahkan pengalaman belajar mahasiswa. Menurut Rudi dalam (Yudi, Ariani, \& Ramadianti, 2017) sumber belajar akan membuat proses belajar mengajar lebih efektif, efisien dan relevan. Dalam hal ini, pengembangan bahan ajar diharapkan akan dapat membuat kemampuan matematis menjadi lebih baik.

Pengembangan bahan ajar adalah sebagai bentuk aktivitas dan proses belajar mengajar dapat membuat kualitas pembelajaran yang ada menjadi lebih baik. Bahan ajar tersebut dapat menghimpun materi-materi dari berbagai sumber sehingga lebih bervariasi dan dapat memberikan pengalaman belajar yang lebih kepada mahasiswa terutama dalam pengembangan kemampuan matematis mahasiswa. Penggunaan bahan ajar dalam proses perkuliahan merupakan salah satu cara untuk mengatasi situasi pembelajaran yang monoton dan cenderung pasif. Dosen akan terbantu untuk mengurangi waktu dalam menjelaskan materi ajar dan mahasiswa akan lebih dapat mengembangkan kemampuannya dan terbantu dalam proses belajarnya.

Mata pelajaran matematika sebagai salah satu ilmu pengetahuan harus mampu menerapkan pendidikan nilai melalui pembelajarannya di kelas. Pembelajaran matematika harus lebih diberdayakan dan diubah menyentuh semua aspek, yaitu spiritual, sosial, pengetahuan, dan keterampilan sehingga berkontribusi lebih besar dalam pembentukkan watak dan kepribadian mahasiswa (Khasanah, 2015).
Pendidikan islam mengajarkan nilai-nilai yang dapat membentuk kepribadian berkarakter, berakhlak mulia dan beradab. Maka pendidikan yang berbasis pada nilai-nilai islam akan membentuk kepribadian yang baik. Nilainilai islam dapat diintegrasikan dalam proses pembelajaran matematika sehingga dapat mengantarkan mahasiswa untuk mencapai pengetahuan, pemahaman dan penerapan nilai-nilai islam. Salah satunya yaitu dengan pengembangan bahan ajar yang berbasis nilai-nilai keislaman.

Pendidikan matematika yang mengandung nilai-nilai islam menempatkan matematika sebagai jalan bagi peserta didik untuk memperbaiki moral peserta didik (Rahmawati \& Rizki, 2017). Dalam pembelajaran matematika, pengetahuan peserta didik tidak hanya pada konsep matematika atau rumusrumus matematika tetapi mengaitkan pembelajaran dengan kehidupan seharihari yang didasari dengan nilai-nilai islam. Hal ini sejalan dengan penelitian yang dilakukan oleh (Mulyanti, Novarina, Haq, \& Nurcahyono, 2017) bahwa dari penelitian tersebut dalam mengimplementasikan bahan ajar berbasis konstruktif nilai-nilai keislaman telah dilaksanakan sesuai yang direncanakan dan mencapai keberhasilan yang dapat dilihat dari pencapaian indikator yang ditetapkan.

Selain itu, salah satu hal yang ingin diintegrasikan kurikulum 2013 ke dalam proses pembelajaran, termasuk proses pembelajaran matematika adalah pendekatan saintifik. Pendekatan saintifik/pendekatan ilmiah adalah proses pembelajaran yang dirancang sedemikian rupa mulai dari proses mengamati, menanya, mengumpulkan data, mengasosiasi, dan mengkomunikasikan, sehingga mendorong perkembangan dan pengembangan kompetensi sikap, pengetahuan dan keterampilan 
mahasiswa menjadi lebih baik serta memenuhi kaidah ilmiah (Wiyanto, 2017). Sedangkan menurut Irwandi dalam (Ine, 2015) pendekatan saintifik merupakan bagian inti dari kegiatan pembelajaran berbasis kontekstual. Pengetahuan yang dimiliki dan yang akan tercipta dapat berbentuk faktual, konseptual, prosedural atau metakognitif yang dapat diperoleh melalui pengalaman indrawi mahasiswa dari berbagai sumber (Wiyanto, 2017). Jika tahapan-tahapan pendekatan saintifik ini dilaksanakan dengan baik maka pembelajaran akan berpusat pada mahasiswa, mahasiswa terbiasa untuk berpikir tingkat tinggi, kemampuan mahasiswa dalam memecahkan masalah berkembang, dan hasil belajar mahasiswa tinggi.

Berdasarkan uraian tersebut, pendekatan saintifik perlu diterapkan dalam proses pembelajaran matematika untuk meningkatkan kualitas mahasiswa. Salah satu hal yang dapat membantu guru dalam melaksanakan proses pembelajaran termasuk proses pembelajaran dengan pendekatan saintifik adalah bahan ajar. Menurut Hifarianti dalam (Asmaranti, Pratama, \& Wisniarti, 2018) bahan ajar yang berkualitas adalah bahan ajar yang memuat kelengkapan dimensi pengetahuan serta dapat melatih tingkatan proses kognitif mahasiswa.

Seperti pada penelitian yang dilakukan oleh (Asmaranti et al., 2018) bahwa di setiap langkah-langkah pendekatan saintifik tersebut disisipkan nilai-nilai pendidikan karakter. Kegiatan mengamati dapat menumbuhkan karakter religius, rasa ingin tahu, dan ketelitian. Kegiatan menanya mendidik karakter rasa ingin tahu, kritis dan jujur. Kegiatan mengumpulkan informasi terdapat karakter teliti, jujur, menghargai orang lain dan kritis. Kegiatan mengolah informasi disisipkan karakter mandiri dan kerja keras. Kegiatan menyimpulkan menumbuhkan karakter jujur, teliti dan kerja keras. Kegiatan mengkomunikasikan menumbuhkan karakter komunikatif dan menghargai orang lain.

Berdasarkan hasil penelitian terdahulu, telah dilakukan penelitian untuk mengembangkan bahan ajar berbasis nilai-nilai keislaman pada peserta didik tingkat SMP, baik mata pelajaran matematika (Mulyanti et al., 2017; Rahmawati \& Rizki, 2017) ataupun IPA (Susilowati, 2017). Perbedaan dengan produk yang dikembangkan peneliti yaitu peneliti mengembangkan bahan ajar pada tingkat perguruan tinggi pada mata kuliah aljabar linier dengan menggunakan pendekatan saintifik.

Penelitian selanjutnya, mengembangkan beberapa macam perangkat pembelajaran (Candra \& Masruri, 2015; Hala, Saenab, \& Kasim, 2016; Kawiyah, 2015; Rusnilawati, 2016; Untayana \& Harta, 2016; Wijayanti, 2014) seperti mengembangkan modul pembelajaran (Puteri \& Susilowibowo, 2014; Setiyadi, Ismail, \& Gani, 2017; Sukiminiandari, Budi, \& Supriyati, 2015; Yesimadesi, Bayharti, Handayani, \& Legi, 2016; Zulkarnain, Kadaritna, \& Tania, 2015), mengembangkan LKS (Yulianti, Indah, \& Kuntjoro, 2014), serta mengembangkan LKPD (Asmaranti et al., 2018). Perbedaan dengan produk yang dikembangkan peneliti yaitu peneliti mengembangkan bahan ajar berbasis nilai-nilai keislaman dengan menggunakan pendekatan saintifik.

Berdasarkan beberapa penelitian terdahulu, peneliti menyimpulkan memberikan alternatif untuk melakukan pengembangan bahan ajar aljabar linier berbasis nilai-nilai keislaman dengan pendekatan saintifik pada materi matriks dan sistem persamaan linier.

\section{METODE}

Penelitian ini menggunakan metode penelitian dan pengembangan (Research 
and Development). Model pengembangan yang digunakan sebagai dasar dalam penelitian ini adalah model ADDIE. Sesuai dengan namanya, model ADDIE terdiri dari lima fase atau tahap utama, yaitu (A)nalysis, (D)esign, (D)evelopment, (I)mplementation, (E)valuation. Kelima fase atau tahap dalam model ADDIE, perlu dilakukan secara sistematik (Kurniati, 2016).

Kelayakan produk yang dikembangkan dilihat dari hasil validasi terhadap para validator yang terdiri dari validator ahli materi, validator ahli media, dan validator ahli agama serta respon dari mahasiswa. Instrumen yang digunakan adalah angket validasi ahli dan angket respon mahasiswa.

\section{HASIL DAN PEMBAHASAN}

Hasil penelitian pengembangan bahan ajar yang diperoleh adalah sebagai berikut:

1. Hasil Validasi Ahli Materi

Berdasarkan hasil validasi ahli materi yang terdiri dari dua validator terhadap 2 aspek penilaian yaitu aspek isi dan aspek kebahasaan. Hasil penilaian oleh kedua validator dapat dilihat pada Tabel 1.

Tabel 1. Hasil Validasi Ahli Materi

\begin{tabular}{ccccc}
\hline \multirow{2}{*}{ Aspek Penilaian } & Validator & Pemberian Skor & Skor Total & Persentase \\
\cline { 2 - 4 } Aspek Isi & Validator 1 & 37 & 90 & $84 \%$ \\
& Validator 2 & 39 & & \\
Aspek & Validator 1 & 20 & 50 & $84 \%$ \\
Kebahasaan & Validator 2 & 22 & & $168 \%$ \\
& & Jumlah & & $84 \%$ \\
& Rata-rata & & Sangat layak \\
\hline
\end{tabular}

Berdasarkan hasil pengisian angket oleh ahli materi diperoleh skor untuk kelayakan aspek isi yaitu 84\%, dan untuk aspek kebahasaan yaitu 84\%. Sehingga diperoleh rata-rata penilaian untuk seluruh aspek pada produk bahan ajar aljabar linier berbasis nilai-nilai keislaman dengan pendekatan saintifik adalah sebesar $84 \%$ yang masuk dalam kategori "Sangat Layak".

Tabel 2. Hasil Validasi Ahli Media

\begin{tabular}{lcccc}
\hline \multicolumn{1}{c}{ Aspek Penilaian } & Validator & $\begin{array}{c}\text { Pemberian } \\
\text { Skor }\end{array}$ & Skor Total & Persentase \\
Aspek Ukuran Bahan Ajar & Validator 1 & 8 & & \\
Aspek Desain Kulit Bahan & Validator 2 & 8 & 20 & $80 \%$ \\
Ajar & Validator 1 & 23 & & \\
Validator 2 & 21 & 60 & $73 \%$ \\
Aspek Desain Isi Bahan Ajar & Validator 1 & 45 & \multirow{2}{*}{120} & $74 \%$ \\
& Validator 2 & 44 & & $227 \%$ \\
& Jumlah & & & $76 \%$ \\
& Rata-rata & & & Layak \\
\hline
\end{tabular}

\section{Hasil Validasi Ahli Media}

Berdasarkan hasil validasi ahli media yang terdiri dari dua validator terhadap 3 aspek penilaian yaitu aspek ukuran bahan ajar, aspek desain kulit bahan ajar, dan aspek desain isi bahan ajar. Hasil penilaian oleh kedua validator dapat dilihat pada Tabel 2 . 
Desimal, 2 (2), 2019 - 159

Dona Dinda Pratiwi

Hasil skor penilaian pada tiap aspek dari kedua ahli media pada aspek ukuran bahan ajar dengan kategori sangat layak yaitu $80 \%$, untuk aspek desain kulit bahan ajar dalam kategori layak juga yaitu 73\%, serta untuk aspek desain isi bahan ajar adalah dalam kategori layak yaitu $74 \%$. Sehingga diperoleh skor ratarata untuk semua aspek yaitu $76 \%$ yang berarti bahan ajar ini dalam kategori layak dari penilaian ahli media.

3. Hasil Validasi Ahli Agama

Berdasarkan hasil validasi ahli agama yang terdiri dari dua validator terhadap 2 aspek penilaian yaitu aspek isi dan aspek kebahasaan.Hasil penilaian oleh kedua validator dapat dilihat pada Tabel 3.

Tabel 3. Hasil Validasi Ahli Agama

\begin{tabular}{clccc}
\hline \multirow{2}{*}{ Aspek Penilaian } & Validator & Pemberian Skor & Skor Total & Persentase \\
Aspek Isi & Validator 1 & 23 & 60 & $77 \%$ \\
& Validator 2 & 23 & & \\
Aspek Kebahasaan & Validator 1 & 15 & 40 & $75 \%$ \\
& Validator 2 & 15 & & $152 \%$ \\
& Jumlah & & $76 \%$ \\
Rata-rata & & Layak \\
& Kriteria & &
\end{tabular}

Hasil skor penilaian pada tiap aspek dari kedua ahli agama pada aspek isi dengan kategori layak yaitu 77\%, untuk aspek kebahasaan dalam kategori layak juga yaitu $75 \%$. Sehingga diperoleh skor rata-rata untuk semua aspek yaitu $76 \%$ yang berarti bahan ajar ini dalam kategori layak dari penilaian ahli agama.

4. Respon Mahasiswa

Uji coba bahan ajar yang telah divalidasi oleh para validator dilakukan terhadap 10 mahasiswa. Data dari angket yang diperoleh dapat dilihat pada Tabel 4.

Tabel 4. Hasil Respon Mahasiswa

\begin{tabular}{|c|c|c|c|c|}
\hline \multirow[b]{2}{*}{ Responden } & \multicolumn{4}{|c|}{ Pemberian Skor Pada Aspek Penilaian } \\
\hline & $\begin{array}{c}\text { Kualitas } \\
\text { Isi }\end{array}$ & $\begin{array}{l}\text { Nilai-Nilai Agama } \\
\text { Islam }\end{array}$ & Tampilan & Bahasa \\
\hline 1 & 16 & 7 & 10 & 6 \\
\hline 2 & 16 & 7 & 12 & 6 \\
\hline 3 & 17 & 7 & 10 & 6 \\
\hline 4 & 17 & 8 & 11 & 6 \\
\hline 5 & 18 & 8 & 12 & 6 \\
\hline 6 & 18 & 7 & 11 & 6 \\
\hline 7 & 19 & 6 & 10 & 6 \\
\hline 8 & 18 & 8 & 11 & 7 \\
\hline 9 & 19 & 8 & 12 & 6 \\
\hline 10 & 19 & 8 & 10 & 7 \\
\hline Jumlah & 177 & 74 & 109 & 62 \\
\hline Total skor & \multicolumn{4}{|c|}{422} \\
\hline Jumlah skor kriterium & \multicolumn{4}{|c|}{480} \\
\hline Presentase & \multicolumn{4}{|c|}{$88 \%$} \\
\hline Kategori & \multicolumn{4}{|c|}{ Sangat Baik } \\
\hline
\end{tabular}


Hasil respon mahasiswa yang terdiri dari 10 orang mahasiswa terhadap bahan ajar aljabar linier berbasis nilai-nilai keislaman dengan pendekatan saintifik diperoleh presentase sebesar 88\% yang berarti bahwa bahan ajar ini sangat baik.

Bahan ajar merupakan bahan ajar yang dikembangkan sebagai fasilitator dalam pembelajaran. Bahan ajar matematika berisi tugas yang harus dikerjakan oleh mahasiswa untuk melatih kemampuan dalam pemahaman matematika. Tujuan dari pengembangan ini adalah menghasilkan bahan ajar matematika berbasis nilai-nilai keislaman dengan pendekatan saintifik pada materi matriks dan sistem persamaan linier yang dapat memudahkan proses pembelajaran.

Prosedur pengembangan yang digunakan dalam pengembangan mengacu pada model pengembangan ADDIE yang terdiri dari lima tahap yaitu Analysis, Design, Development, Implementation, Evaluation.

Sistematika bahan ajar matematika yang disajikan secara berurut, yaitu bagian awal, bagian isi dan bagian penutup. Pada bagian awal ini terdiri dari halaman depan (cover luar), kata pengantar dan daftar isi. Bagian isi terdiri dari uraian materi dan aktivitasaktivitas/latihan soal untuk melatih kemampuan mahasiswa. Bagian penutup terdiri dari glosarium dan daftar pustaka.

Bahan ajar aljabar linier berbasis nilai-nilai keislaman dengan pendekatan saintifik secara keseluruhan telah melalui tahapan-tahapan validasi oleh para ahli materi, ahli media dan ahli agama dan sudah dilakukan perbaikanperbaikan sesuai saran para validator sehingga dikatakan bahwa bahan ajar matematika yang dikembangkan oleh peneliti layak untuk digunakan dalam pembelajaran. Berdasarkan reaksi yang ditunjukkan oleh mahasiswa saat uji coba lapangan, terlihat bahwa mahasiswa tertarik dengan bahan ajar ini karena bahan ajar matematika dikaitkan dengan nilai-nilai keislaman sehingga wawasan peserta didik dapat bertambah. Mahasiswa dapat memahami kaitan matriks dengan nilainilai keislaman, seperti pada shaf shalat, dan dapat memahami kaitan matriks dengan kehidupan sehari-hari seperti pada baris berbaris. Selain itu, pada materi sistem persamaan linier, mahasiswa dapat mengetahui kaitan sistem persamaan linier yang berupa perumpamaan simbol-simbol matematika seperti variabel $x, y$, dan $z$ dengan nilai-nilai keislaman yaitu bahwa di dalam ayat Al-Qur'an Allah SWT juga membuat perumpamaan terhadap makhluknya.

Berdasarkan penelitian terdahulu, telah dilakukan beberapa penelitian yang mengembangkan bahan ajar, beberapa diantaranya mengembangkan bahan ajar berbasis pendekatan saintifik (Mardiana, 2018) serta mengembangkan bahan ajar berbasis nilai-nilai keislaman (Mulyanti et al., 2017; Rahmawati \& Rizki, 2017; Susilowati, 2017). Berdasarkan penelitian terdahulu, keterbaruan dalam penelitian ini terletak pada bahan ajar aljabar linier berbasis nilai-nilai keislaman dengan pendekatan saintifik menambah wawasan mahasiswa tentang kaitan antara matriks dan sistem persamaan linier dengan nilai-nilai Islam, bahan ajar aljabar linier berbasis nilai-nilai keislaman memuat informasi tentang ilmuan Islam serta ayat-ayat Al-Qur'an yang berhubungan dengan ilmu matematika sehingga dapat menambah pengetahuan mahasiswa serta bahan ajar aljabar linier berbasis nilai-nilai keislaman dengan pendekatan saintifik memberi kesempatan kepada mahasiswa untuk mengamati langsung objek yang akan dipelajari dan membuat 
mahasiswa aktif bertanya terhadap materi yang belum dipahaminya, bahan ajar dengan pendekatan saintifik juga meningkatkan aktfitas berfikir/bernalar mahasiswa dimana mahasiswa dapat bernalar tentang kaitan antara matriks dan sistem persamaan linier dengan hubungan ayat-ayat Al-Qur'an dan kehidupan sehari-hari, memberikan kesempatan kepada mahasiswa untuk menuangkan ide/informasi yang diperoleh dalam memecahkan permasalahan matematika, dan membuat mahasiswa mampu menyimpulkan sendiri pengetahuan yang diperolehnya.

\section{SIMPULAN DAN SARAN}

Berdasarkan hasil penelitian dan pengembangan yang dilakukan oleh peneliti, maka dapat disimpulkan bahwa setelah dilakukan analisis maka sangat perlu dikembangkan suatu produk bahan ajar aljabar linier berbasis nilainilai keislaman dengan pendekatan saintifik. Produk dirancang dengan memperhatikan bagian awal, isi, dan penutup. Selanjutnya bahan ajar dikembangkan dengan divalidasi, dan direvisi untuk mengetahui kelayakan produk. Berdasarkan penilaian dari ahli materi diperoleh skor penilaian yang cukup tinggi dengan kategori "Sangat Layak", serta ahli media dan ahli agama diperoleh skor penilaian dengan kategori "Layak". Setelah dikembangkan, bahan ajar diimplementasikan atau diujicobakan untuk mengetahui respon mahasiswa. Berdasarkan uji coba tersebut diperoleh respon yang sangat bagus dari mahasiswa dengan skor penilaian dalam kategori "Sangat Baik".

Berdasarkan hasil penelitian yang diperoleh, maka peneliti memberikan saran yang sekiranya dapat menjadi bahan pertimbangan untuk penelitian selanjutnya yaitu bahan ajar aljabar linier berbasis nilai-nilai keislaman dengan pendekatan saintifik dapat dikembangkan pada beberapa mata kuliah lain serta materi yang lebih luas dan bahan ajar aljabar linier berbasis nilai-nilai keislaman dengan pendekatan saintifik yang masih memiliki banyak kekurangan dalam proses pembuatan dan pengembangannya sehingga peneliti selanjutnya dapat termotivasi mengembangkan bahan ajar ini lebih baik lagi, agar membuat minat mahasiswa dalam mengikuti pembelajaran semakin tinggi.

\section{DAFTAR PUSTAKA}

Asmaranti, W., Pratama, G. S., \& Wisniarti. (2018). Desain Lembar Kerja Peserta Didik (LKPD) Matematika dengan Pendekatan Saintifik Berbasis Pendidikan Karakter. In Prosiding Seminar Nasional Etnomatnesia (pp. 639646).

Candra, A. A., \& Masruri, M. S. (2015). Pengembangan Multimedia Interaktif dengan Pendekatan Saintifik untuk Pembelajaran PKN SMP. Harmoni Sosial: Jurnal Pendidikan IPS, 2(2), 109-114.

Hala, Y., Saenab, S., \& Kasim, S. (2016). Pengembangan Perangkat Pembelajaran Biologi Berbasis Pendekatan Saintifik pada Konsep Ekosistem Bagi Siswa Sekolah Menengah Pertama. Journal of Est, 1(3), 85-96.

Ine, M. E. (2015). Penerapan Pendekatan Scientific untuk Meningkatkan Prestasi Belajar Siswa pada Mata Pelajaran Ekonomi Pokok Bahasan Pasar. In Prosiding Seminar Nasional (pp. 269-285).

Kawiyah, S. (2015). Pengembangan Perangkat Pembelajaran Matematika Berbasis Saintifik untuk Meningkatkan Kemampuan Pemecahan Masalah dan Prestasi Belajar Siswa. Pythagoras: Jurnal 
Pendidikan Matematika, 10(2), 201-210.

Kurniati, A. (2016). Pengembangan Modul Matematika Berbasis Kontekstual Terintegrasi Ilmu Keislaman. Al-Khawarizmi: Jurnal Pendidikan Matematika dan Ilmu Pengetahuan Alam, 4(1), 43-58.

Kusumam, A., Mukhidin, \& Hasan, B. (2016). Pengembangan Bahan Ajar Mata Pelajaran Dasar dan Pengukuran Listrik untuk Sekolah Menengah Kejuruan. Jurnal Pendidikan Teknologi dan Kejuruan, 23(1), 28-39.

Mardiana, E. (2018). Pengembangan Bahan Ajar Berbasis Pendekatan Saintifik Meningkatkan Kemampuan Literasi Matematika Siswa Pascasarjana, Universitas Negeri Malang. In Prisma: Prosiding Seminar Nasional Matematika (Vol. 1, Pp. 87-91).

Mulyanti, Y., Novarina, E., Haq, A. M. I., \& Nurcahyono, N. A. (2017). Ibm terhadap Guru-Guru Matematika SMP Muhammadiyah 1 Kota Sukabumi dan SMP Muhammadiyah 6 Sukaraja dalam Menyusun dan Mengimplementasikan Bahan Ajar Berbasis Konstruktif Islami. EDimas, 8(2), 197-205.

Puteri, L. C. P. S., \& Susilowibowo, J. (2014). Pengembangan Modul Akuntansi Berbasis Pendekatan Saintifik sebagai Bahan Ajar Pendukung Implementasi Kurikulum 2013 pada Materi Pokok Piutang Kelas XI di SMK Negeri 1 Ngawi. Jurnal Pendidikan, 4(3), 1-6.

Rahmawati, A., \& Rizki, S. (2017). Pengembangan Bahan Ajar Matematika Berbasis Nilai-nilai Islam pada Materi Aritmatika Sosial. Aksioma, 6(1), 81-88.

Rusnilawati, R. (2016). Pengembangan Perangkat

Pembelajaran
Matematika Bercirikan Active Knowledge Sharing dengan Pendekatan Saintifik Kelas VIII. Jurnal Riset Pendidikan Matematika, 3(2), 245-258.

Setiyadi, M. W., Ismail, \& Gani, H. A. (2017). Pengembangan Modul Pembelajaran Biologi Berbasis Pendekatan Saintifik untuk Meningkatkan Hasil Belajar Siswa. Journal of Educational Science And Technology, 3(2), 102-112.

Sukiminiandari, Y. P., Budi, A. S., \& Supriyati, Y. (2015). Pengembangan Modul Pembelajaran Fisika dengan Pendekatan Saintifik. In Prosiding Seminar Nasional Fisika (E-Journal) Snf2015 (Vol. IV, pp. 161-164).

Susilowati, S. (2017). Pengembangan Bahan Ajar IPA Terintegrasi Nilai Islam untuk Meningkatkan Hasil Belajar IPA. Jurnal Inovasi Pendidikan Ipa, 3(1), 78-88.

Untayana, J. R., \& Harta, I. (2016). Pengembangan Perangkat Pembelajaran Limit Berbasis Pendekatan Saintifik Berorientasi Prestasi Belajar dan Kemampuan Komunikasi Matematika. Jurnal Riset Pendidikan Matematika, 3(1), 45-54.

Wijayanti, A. (2014). Pengembangan Autentic Assesment Berbasis Proyek dengan Pendekatan Saintifik untuk Meningkatkan Keterampilan Berpikir Ilmiah Mahasiswa. Jurnal Pendidikan IPA Indonesia, 3(2), 102-108.

Wiyanto. (2017). Pendekatan Saintifik pada Perkuliahan dengan Sistem E-Learning. Integralistik, XXVIII(2), 217-229.

Yesimadesi, Bayharti, Handayani, F., \& Legi, W. F. (2016). Pengembangan Modul Kesetimbangan Kimia Berbasis Pendekatan Saintifik Untuk Kelas XI SMA/MA. Journal of Sainstek, 8(1), 85-97. 
Desimal, 2 (2), 2019 - 163

Dona Dinda Pratiwi

Yudi, M., Ariani, N. M., \& Ramadianti, W. (2017). Desain Bahan Ajar Mata Kuliah Alajabar Linear untuk Mengembangkan Kemampuan Berfikir Kreatif Matematis. Kalamatika Jurnal Pendidikan Matematika, 2(1), 1-14.

Yulianti, E., Indah, N. K., \& Kuntjoro, S. (2014). Validitas LKS Pengamatan Berdasarkan Pendekatan Saintifik pada Sub Pokok Bahasan Angiospermae. Bioedu: Berkala Ilmiah Pendidikan Biologi, 3(3), 606-609.

Zulkarnain, A., Kadaritna, N., \& Tania, L. (2015). Pengembangan E-Modul Teori Atom Mekanika Kuantumberbasis Web dengan Pendekatan Saintifik. Jurnal Pendidikan dan Pembelajaran Kimia, 4(1), 222-235. 